\title{
Study Habits and English Learning Achievement of Vocational High School Students in Samarinda
}

\author{
Asyarli Amri \\ English Education \\ Mulawarman University \\ Samarinda, Indonesia \\ asyarliamri@yahoo.co.id
}

\author{
Aridah \\ English Education \\ Mulawarman University \\ Samarinda, Indonesia \\ aridah27@gmail.com
}

\author{
Weningtyas ParamaIswari \\ English Education \\ Mulawarman University \\ Samarinda, Indonesia \\ weningtyas.iswari@gmail.com
}

\begin{abstract}
The process of students' learning involves many factors, and one of which is study habits. This important factor in the learning process has the potential to influence students' learning achievement. Therefore, this present study aimed to investigate the correlation between study habits and English learning achievement of the first-grade students of a state vocational school - SMKN 12 in Samarinda. This study employed a quantitative research method with correlational design. Sixty five students were selected as sample using the purposive technique. The instruments used to collect data included the Study Habits Inventory and documents (i.e. the students' English midterm scores) as the students' English learning achievement. Descriptive statistics and Pearson Product Moment Correlation were used to analyze the data. The result indicated that there was a positive correlation between study habits and English learning achievement. Therefore, it can be concluded that the better the students' study habits, the higher their learning achievement.
\end{abstract}

Keywords: study habits, learning achievement, Samarinda

\section{INTRODUCTION}

Learning achievement occupies a very important place and even becomes one of the major goals of students' educational process [1]. There are various factors that may be affected learning achievement, such as intelligence, students' attitude, personality, socioeconomic status, and study habits [2]. Study habits were found giving influences on students' learning achievement [3]. The study habits was defined as "The student's way of study whether systematic, efficient or inefficient, etc." [4]. Study habits are the behavior of an individual related to studies [5]. Meanwhile study habits as the sum total of all habits and practices that the individual uses in order to learn [6]. In addition, study habits as the regular tendencies and practices that one depicts during learning process [7]. Based on that, the researchers believe study habits as the students' behavior and/or practice done in the same way from time to time, until they do it automatically and it becomes their habits during studies.

There are some experts who have grouped several areas or domains in study habits. the effective or good study habits areas include a plan/place, a definite time table and taking brief, well-organized notes [3]. Furthermore, study habits that include time management, note taking, internet skills, eliminatory distractions, and prioritized studies [8]. Moreover Arora has listed some good study habits that lead to better academic achievement: attending class regularly, note taking, concentration on study, studying with aim of getting meaning not cramming, having proper test periods, facing the problems regarding home environment and planning, and preparing and following timetable [6]. While, Palsane and Sharma has divided study habits in eight areas: budgeting time, physical condition for study, reading ability, taking notes, motivation, memory, holding examination, and health. In this present study, the researchers were interested to investigate students' study habits which consist of eight areas [9]. The following are the details explanation of each area.

\section{- Budgeting Time}

Budgeting time is known as time management. The time management as the art of arranging, organizing, scheduling, and budgeting one's time [10]. Meanwhile, time schedule helps to adjust the study periods and other activities according to the needs of the individual [9]. By budgeting time, students can optimize their success in study as well as their extra-curricular activities. Managing time effectively helps the students to develop better personality in organizing a study [11].

\section{- Physical conditions for study}

The condition or environment of study should have good circulated air, be calm and quiet, and bright lighted room or open place with desks and chairs used for study [12]. Study table should be clean and contain only all necessary things, such as: papers, pen and pencil [9].

\section{- Reading ability}

Reading is a mechanic process involving the brain and other organs, and if it is frequently carried out, it becomes a habit [13]. Reading is a prerequisite of effective study habits which will help the students to improve their academic performance. A study revealed that reading habits have significant effect on academic performance of the students [14]. The use of library is also important in shaping students' habit in reading for leisure, study and information [15].

\section{- Taking notes}

Taking notes contributes a great deal in study habits [9]. If students take a note in their study, they will be more focused on their idea and speed up in learning process [16]. With the help of regular practice note-taking can become a habit.

\section{- Learning motivation}

Motivation as the reason for people's action, desire, and needs [17]. Motivation is also one's direction to behavior, or what causes a person to repeat behavior as their habits. 
Apart from ability to learn, desire to learn is an important consideration which may influence motivation [9]. Meanwhile, the motivation as one of the main determinants of successful foreign languages learning [18].

\section{- Memorization}

Improving memory means learning better [9]. It means we need to review the material continuously. In addition, memorization as a cognitive strategy that focuses on the storages for retrieval information of language [19]. In this sense, memorization has the potential as a tool for internalization of what has been learned by the students and its application in real communication [20].

\section{- Taking examinations}

Examinations are frequently in the form of essays where a few questions are given and students are required to write long answers. Students might prepare an outline and arrange the ideas properly, following a logical pattern of presentation.

\section{- Preparation for examination}

Calm, cool and relaxed attitude towards the examination is necessary and can be achieved only after a good preparation [9]. A study revealed that by applying good strategies in preparation examination, the students were more prepared to answer the questions and in return they achieved maximum scores [21].

\section{- Use of examination results}

Results of examination can be an indicator of one's strong and weak points. Knowledge of results can motivate an individual and direct his/her efforts [9].

\section{- Health}

Health was dealing with the students' feeling, emotion and mental of study. Regular and healthy habits of eating, exercise, recreation and sleep help in maintaining good health and sound mental state which is necessary to achieve success in the examination [9].

The study habits play an important role in learning achievement. The good study habits have good effects towards academic achievement. Several studies on study habits have proved a significant correlation between study habits and students' language achievement [3,4,22,23]. Only few studies concluded the opposite; one of which is Lawrence study that showed no significant relationship between study habits and achievement [24].

In Indonesia where English is considered as a foreign language, it is not easy for students to put sufficient efforts to develop good study habits in their study to obtain good grades. Therefore, the aimed of this present study was to find out the students' study habits, students' English learning achievement, and to examine the correlation between those two variables. This study focused on the first-grade students of a state vocational school in Samarinda, Indonesia.

\section{METHOD}

The correlation design was used in the frame of quantitative approach. The population of this study was the first-grade students of SMKN 12 Samarinda in the academic year 2018/2019. There were 8 classes (Akutansi 1, Akutansi 2, $A P$ 1, AP 2, BO, TKJ, OT 1, and OT 2) with total number 222 students. A sample of this study was 65 students who were selected through purposive technique. Data were collected from documentation (students' English mid-term scores) and a questionnaire Study Habits Inventory (SHI). The students' English mid-terms scores were categorized into four levels based on the school's criteria with the minimum passing grade of 75 . The maximum score from 93-100 is categorized Excellent, the score from 84-92Good, the score from 76-83 Fair, and the score below 75 is categorized Poor. The Study Habits Inventory was used to measure the students' study habits. This 3-point Likert scale was constructed by [9] consists of 45 items. Scores ranging from 1.36-2.00 is categorized as Good study habits, from $0.68-1.35$ as Average, and 0-0.67 as Poor. The data was analyzed through descriptive statistics and Pearson Product Moment Correlation by using SPSS Version 23.

\section{RESULTS AND DISCUSSION}

\section{A. Results}

The data were collected from the result of the Study Habit Inventory and English mid-term scores. Based on the descriptive statistics, the score range of $\mathrm{SHI}$ is 0.82 with the minimum score of 0.73 and the maximum score of 1.56 . Meanwhile, the sum score of the students' study habits is 77.10 and the mean is 1.17 . This mean score indicates that the level of the students' study habits was at average level (see Table 1).

TABLE 1. DESCRIPTIVE STATISTICS OF STUDENTS’ STUDY HABITS

\begin{tabular}{|l|c|c|c|c|c|c|}
\hline & N & Range & Minimum & Maximum & Sum & Mean \\
\hline $\begin{array}{l}\text { Study } \\
\text { Habit }\end{array}$ & 65 & 0.82 & 0.73 & 1.56 & 77.1 & 1.17 \\
\hline
\end{tabular}

The level distribution of the students' study habits can be seen in Table 2.

TABLE 2. Distribution of Students' StUdy Habits

\begin{tabular}{|c|c|c|c|}
\hline $\begin{array}{c}\text { Score } \\
\text { Interval }\end{array}$ & Category & Frequency & Percentage \\
\hline $\mathbf{1 . 3 6}-\mathbf{2 . 0 0}$ & Good & 8 & $12 \%$ \\
\hline $\mathbf{0 . 6 8}-\mathbf{1 . 3 5}$ & Average & 57 & $88 \%$ \\
\hline $\mathbf{0}-\mathbf{0 . 6 7}$ & Poor & - & $0 \%$ \\
\hline \multicolumn{2}{|c|}{ Total } & 65 & $100 \%$ \\
\hline
\end{tabular}

Table 2 demonstrates that most of the students $(88 \%)$ had average study habits. Only 8 students $(12 \%)$ were categorized as having good study habits and none of the students had poor study habits. More detailed data were presented by study habit area as presented in Table 3 .

TABle 3. The Mean Scores of the StUdy Habit AREas

\begin{tabular}{|c|c|c|}
\hline \multirow{2}{*}{ Budgeting time } & \multicolumn{2}{|c|}{ Mean } \\
\cline { 2 - 3 } & Statistic & Std. Error \\
\hline Physical condition & 1.15 & 0.044 \\
\hline Reading ability & 1.01 & 0.037 \\
\hline Taking note & 1.08 & 0.032 \\
\hline Learning motivation & 1.10 & 0.050 \\
\hline Memorization & 1.42 & 0.037 \\
\hline
\end{tabular}




\begin{tabular}{|c|c|c|}
\hline Taking examination & 1.19 & 0.025 \\
\hline Health & 1.15 & 0.035 \\
\hline
\end{tabular}

Table 3 presents the different level of each area of study habits. The result indicated that learning motivation became the only area that belonged to Good category $(M=1.42)$, while the other areas of study habits were at Average category and no area was at Poor category.

Another variable addressed in this research was English learning achievement. The result of descriptive statistics of the students' English achievement can be seen in Table 4.

TABLE 4. DescriPtive Statistics of STUDENTS’ ENGLiSh LEARNING ACHIEVEMENT

\begin{tabular}{|c|c|c|c|c|c|c|}
\hline & N & Range & Minimum & Maximum & Sum & Mean \\
\hline $\begin{array}{l}\text { English } \\
\text { achieve } \\
\text { ment }\end{array}$ & 65 & 32 & 56 & 88 & 4962 & 76.34 \\
\hline
\end{tabular}

Based on Table 4, the range of English learning achievement was 32 with the minimum score of 56and the maximum score of 88. The mean score was 76.34 (Fair). The distribution of the English learning achievement results are presented in Table 5.

TABLE 5. Distributions OF STUDENTS' ENGLiSH ACHIEVEMENT

\begin{tabular}{|c|c|c|c|}
\hline $\begin{array}{c}\text { Score } \\
\text { Interval }\end{array}$ & Category & Frequency & Percentage \\
\hline $93-100$ & Excellent & 0 & $0 \%$ \\
\hline $84-92$ & Good & 15 & $23 \%$ \\
\hline $76-83$ & Fair & 34 & $52 \%$ \\
\hline$<75$ & Poor & 16 & $25 \%$ \\
\hline \multicolumn{2}{|c|}{ Total } & 65 & $100 \%$ \\
\hline
\end{tabular}

With regards to English learning achievement, there were no students in Excellent category. Slightly more than half of the students $(52 \%)$ were in Fair category. The rest gained higher scores (23\% at Good category) and lower scores (25\% at Poor category).

The statistical testing of the correlation between study habits and English learning achievement by using Pearson Product Moment Correlation was presented in Table 6.

TABle 6. The CORRELATION RESUlt

\begin{tabular}{|c|c|r|r|}
\hline \multicolumn{2}{|c|}{} & $\begin{array}{c}\text { Study } \\
\text { Habits }\end{array}$ & $\begin{array}{c}\text { English } \\
\text { Achievement }\end{array}$ \\
\hline \multirow{2}{*}{$\begin{array}{c}\text { Study } \\
\text { Habits }\end{array}$} & $\begin{array}{c}\text { Pearson } \\
\text { Correlation }\end{array}$ & 1 & $0.368^{* *}$ \\
\cline { 2 - 4 } & Sig. (2-tailed) & & 0.003 \\
\cline { 2 - 4 } & $\mathrm{N}$ & 65 & 65 \\
\hline $\begin{array}{c}\text { English } \\
\text { Achievem } \\
\text { ent }\end{array}$ & $\begin{array}{c}\text { Pearson } \\
\text { Correlation }\end{array}$ & $0.368^{* *}$ & 1 \\
\cline { 2 - 4 } & Sig. (2-tailed) & 0.003 & 65 \\
\cline { 2 - 4 } & N & 65 & \\
\hline \multirow{2}{*}{$* *$ N Correlation }
\end{tabular}

**. Correlation is significant at the 0.01 level (2-tailed).

The $r$ value is 0.368 and higher than $r$ table (0.244). It represents a positive correlation between study habits and English learning achievement. The correlation was positive and significant at $\mathrm{p}<0.01$.It implies that students with a higher level of study habits were benefited in terms of having higher English learning achievement. More detailed data on the correlation of study habit areas and English learning achievement are presented in Table 7.
TABLE 7. THE CORRELATION OF STUDY HABIT AREAS AND ENGLISH LEARNING ACHIEVEMENT

\begin{tabular}{|c|c|c|}
\hline \multicolumn{2}{|c|}{ Areas } & English Achievement \\
\hline Budgeting time & $\mathrm{r}$ & $0.412^{* *}$ \\
\cline { 2 - 3 } & $\mathrm{Sig}$ & 0.001 \\
\hline Physical condition & $\mathrm{r}$ & 0.052 \\
\cline { 2 - 3 } & $\mathrm{Sig}$ & 0.681 \\
\hline Reading ability & $\mathrm{r}$ & 0.145 \\
\cline { 2 - 3 } & $\mathrm{Sig}$ & 0.248 \\
\hline \multirow{2}{*}{ Taking note } & $\mathrm{r}$ & -0.001 \\
\cline { 2 - 3 } & $\mathrm{Sig}$ & 0.993 \\
\hline \multirow{2}{*}{$\begin{array}{c}\text { Learning } \\
\text { Motivation }\end{array}$} & $\mathrm{r}$ & $0.304^{*}$ \\
\cline { 2 - 3 } & $\mathrm{Sig}$ & 0.014 \\
\hline \multirow{2}{*}{ Memorization } & $\mathrm{r}$ & $0.268^{*}$ \\
\cline { 2 - 3 } & $\mathrm{Sig}$ & 0.031 \\
\hline Taking examination & $\mathrm{r}$ & $0.272^{*}$ \\
\cline { 2 - 3 } & $\mathrm{Sig}$ & 0.029 \\
\hline \multirow{2}{*}{ Health } & $\mathrm{r}$ & 0.038 \\
\cline { 2 - 4 } & $\mathrm{Sig}$ & 0.761 \\
\hline
\end{tabular}

Table 7 shows the correlation between different areas of study habits and English learning achievement. Of eight study habit areas, four areas had a significant correlation with English learning achievement. These four areas included budgeting time (strongest correlation, $r=.412$ ), learning motivation $(r=.304)$, taking examination $(r=.272)$, and memorization (lowest correlation, $r=.268$ ). The other four areas (that are physical condition, reading ability, taking note and health) had no correlation to English learning achievement.

\section{B. Discussion}

This study has revealed a significant correlation between study habits and English learning achievement. This result was in conformity with the results of previous studies $[22,25,5,6]$ who found a strong relationship between study habits and the students' English achievement. However, compared to the current study their study identified different areas which had no correlation with learning achievement, they are: memorization and preparation for exam. In different areas which did not correlate with learning achievement, namely reading ability, note taking and taking examination [23].

The result showed that the students' study habits were at average category and the students' achievement was also at average category. The highest level of study habit areas was learning motivation, which contributed to good study habits. It can be said that the students were having high motivation to study. Motivation becomes the reason for people's action, desire, needs and causes to repeat behaviors as their habits [17].

Apart from those similar findings, there are some studies which did not find a significant correlation between study habits and academic achievement [24,26,27]. In this vein, the effect of study habits vanished when other variables were controlled. It was perhaps caused by another 
factor which was more dominant and gave more contribution, such as: intelligence, personality, students' attitude toward school, and socioeconomic status [2].

\section{Pedagogical Implications}

The findings of this study have some pedagogical implications for English teachers and students. It is known that there is a significant correlation between study habits and achievement, therefore, teachers should nurture good study habits, especially on the following areas: budgeting time, learning motivation, memorization, examination taking, because these areas had a significant correlation with English learning achievement. By possessing those areas of study habits, students will be able to develop their own good habits by themselves.

In this present study learning motivation had the highest correlation with English learning achievement. Therefore, it is likely that students' learning motivation is important for the achievement of better learning performance. The learning process will be successful when students are motivated to learn. Therefore, the English teachers should pay attention to students' learning motivation in order to improve their achievement. In this context, of course it is the responsibility of the teachers to maintain and increase students' motivation to learn and to find ways to improve student learning, ways to foster lower learning spirit, and ways to increase self-motivation and ways of how to cultivate students' self-motivation. For example, a teacher may motivate the students by giving information about why they should learn English and explaining how important English is for their future career. In order to make English more interesting for students, proposed some strategies that can be used by teachers in motivating their students in learning English [28]. The strategies include: giving praise, giving suggestions, and playing motivation videos. Teacher is required to be creative in arousing students' motivation to obtain optimal learning result and to form effective student learning behaviors.

Generally, study habits can be classified into two good study habits and bad study habits. Good study habits are sometimes referred to as positive or productive study habits [29]. Therefore, the students can build good study habits by doing positive habits in learning. Harper and Row state there are some positive study habits the students can do, such as: studying every day, attending class regularly, always managing time on study, taking note, asking for help if facing problems with the study, and preparing for the examination [30]. By doing those positive things on study, the students will develop their own good habits by themselves [31].

\section{CONCLUSION}

To conclude, the students' study habits were at average category, and their English learning achievement was also at average category. The study showed that study habits and English learning achievement had a significant correlation. It indicates that study habits have an important role in students' English learning achievement. With regard to the significant correlation between study habits and learning achievement it is suggested that study habits be considered as one of the factors used to improve students' achievement.
First, English teacher should nurture and encourage students to build good study habits, such as maintaining students' motivations on study. Second, students themselves need to consider of their study habits and build good study habits, such as studying everyday and prepare for the examination on their learning in order to improve their learning outcomes. Finally, for future researchers, it is suggested that they include other factors related to study habits, such as home environment and planning of work. They can also expand their study to deep exploration of each study habits area by using qualitative or mixedmethods to capture a more comprehensive understanding on study habits.

\section{REFERENCES}

[1] B.Y. Illahi, and H. Khandai, "Academic achievement and study habits of college students of District Pulwana," Journal of Education and Practice, vol.6. pp.1-6, 2015.

[2] N.V. Gudaganavar and R.B. Halayannavar, "Influence of study habits on academic performance of higher primary school students," International Journal of Science and Research, vol.3. pp. 277-280, February 2014.

[3] F.A. Paramika, "The correlation between study habits and academic achievement of undergraduate EFL students of English education study program of UIN Raden Fatah Palembang" Undergradute Thesis. Palembang: Islamic State University, 2017, in press.

[4] S.S. Sabbah, "The effect of study habits on English language achievement," Arab World English Journal, vol. 7. pp. 238257. December, 2016.

[5] K. Yazdani, and V.S. Godbole, "Studying the role of habits and achievement motivation in improving students' academic performance," European Online Journal of Natural and Social Sciences, vol. 3. pp. 827-839, September, 2014.

[6] R. Arora, "Academic achievement of adolescents in relation to study habits," The International Journal of Indian Psychology, vol.3. pp.47-54, March 2016.

[7] O.E. Monica, "Influence of study habits on the academic achievement of students in home economics in junior secondary school in Enugu State," International Journal of Innovative Education Research, vol.3. pp.15-22, December, 2015.

[8] P.T. Lee, “Asian students' perceptions of their own study habits," vol.5. pp.1- 14, 2010.

[9] M.N. Palsane, and S. Sharma, "A consumable booklet of SHI (English Version)," Agra, India: National Psychological Corporation. 2003.

[10] F.A. Adebayo, “Time management and students' academic performance in Higher Institution, Nigeria" International Research in Education, vol.3. pp.1-12, April 2015.

[11] K. Abban, "Understanding the importance of time management to assistant registrar's in the registrars department of the University of Education," International Journal of Scientific \& Engineering Research, vol.3. pp.1-16, December 2012.

[12] G.I. Osa-Edoh and A.N.G. Alutu, "A survey of students study habits in selected secondary schools: implication for counseling" Current Research Journal of Social Sciences, vol.4. pp.228-234. April, 2012.

[13] F.O. Florence, O.A. Adesola, B.A. Hameed, and O.M. Adewumi, "A Survey on the Reading Habits among Colleges of Education Students in the Information Age," Journal of Education and Practices, vol.8. pp.106-110, 2017.

[14] O.C.Daniel, S.R. Esoname, O.D. Chima, and O.S. Udoaku, "Effect of reading habits on the academic performance of students: A case study of the students of AfeBabalola 
University, Ado-Ekiti, Ekiti State,"Teacher Education and Curriculum Studies, vol.2. pp.74-80, January 2017.

[15] A. George, "The school library in a megacity setting: the case of Lagol State, vol.14. pp.76-78, 2011.

[16] F. Boch and A. Piolat, "Note taking and learning: A summary of research," The WAC Journal, vol.16. pp. 101-113, September 2005.

[17] D. Sharma and S. Sharma, "Relationship between motivation and academic achievement," International Journal of Advances in Scientific Research, vol.4. pp.1-5. February, 2018.

[18] N. Rachvelishvili, "Achievement motivation toward learning English language in modern educational context of Georgia," vol.75. 2017, retrieved from researchgate.net on April 2th 2019.

[19] N.M. Alieh and N.M. Atefeh, "Memorization makes progress" Theory and Practices in Language Studies, vol.5. pp.870-874, April 2015.

[20] D.T.H. Oanh, and N.T. Hien, "Memorization and EFL students' strategies at university level in Vietnam," Teaching English as a Second or Foreign Language, (TESL-EJ), vol. 10. pp.01-21. September, 2006.

[21] N. Hawley, D. Johnson, K. Packer, M. Ditmyer, K.Kingsley, "Dental students' preparation and study habits for the National Board Dental Examination Part I," vol.73. pp. 12741278, November 2009.

[22] S.H. Rana, and R. Kausar, "Comparison of study habits and academic performance of Pakistani British and white British students," Pakistan Journal of Social and Clinical Psychology, vol.9. pp. 21-26, 2011

[23] S. Jafri, "Impact of family climate, mental health, study habits and self-confidence on the academic achievement of senior secondary students," Doctor of Philosophy in Education Thesis. India: Aligarh Muslim University., in press, 2011.

[24] A.S.A. Lawrence, "Relationship between study habits and academic achievement of higher secondary school students," Indian Journal of Applied Research, vol. 4. pp. 143-145, June, 2015.

[25] J.W. Creswell, "Educational research: Planning, conducting, and evaluating quantitative and qualitative research (5th ed.)", Upper Saddle River, NJ: Pearson Education, Inc. 2012

[26] Alrefaai, Saiful and Salahud, "The general study habits of major EFL students in King Khalid University and their relationships with GPA, gender and certain social factors," Umm Al-Qurma University Journal of Languages and Literatures, vol.10. pp. 9-63, May 2013.

[27] E. Nouhi, A. Shakoori and N. Nakhei, "Study habits and skills, and academic achievement of students in Kerman University of medical sciences," Journal of Medicine Edition, vol.12. pp. 77-80. August, 2009.

[28] V. Thapar, and A. Kumar, "Academic achievement of Truants in relation to study habits and guidance needs," International Journal of Advanced Research, vol.3. pp. 1344-1349. June, 2015.

[29] Wahyudi, "The strategies of the teacher in motivating their students in learning Englis, A Study at the tenth grade MAN 2 Boyolali in the academic year 2016/2017. Undergraduate Thesis. The state Islamic Institute of Surakarta : Surakarta, 2017, in press.

[30] F. Katelyn, "College Study Habits News," retrieved from www.studymode.com/essays on July 5th 2019.

[31] E.F. Uju and O.A. Paul, "Study habit and its impact on secondary school students' academic performance in Biology in the Federal Capital Territory, Abuja," Educational Research and Reviews, vol.10. pp.583-588, May 2017. 